\title{
Ulcers in leprosy patients, an unrecognized clinical manifestation: a report of 8 cases
}

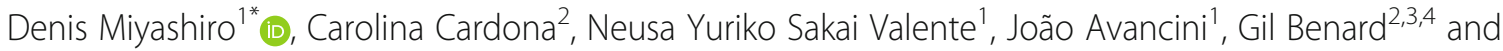 \\ Maria Angela Bianconcini Trindade
}

\begin{abstract}
Background: Leprosy is a chronic granulomatous infection caused by Mycobacterium leprae. It is a polymorphic disease with a wide range of cutaneous and neural manifestations. Ulcer is not a common feature in leprosy patients, except during reactional states, Lucio's phenomenon (LP), or secondary to neuropathies.

Cases presentation: We report eight patients with multibacillary leprosy who presented specific skin ulcers as part of their main leprosy manifestation. Ulcers were mostly present on lower limbs (eight patients), followed by the upper limbs (three patients), and the abdomen (one patient). Mean time from onset of skin ulcers to diagnosis of leprosy was 17.4 months: all patients were either misdiagnosed or had delayed diagnosis, with seven of them presenting grade 2 disability by the time of the diagnosis. Reactional states, LP or neuropathy as potential causes of ulcers were ruled out. Biopsy of the ulcer was available in seven patients: histopathology showed mild to moderate lympho-histiocytic infiltrate with vacuolized histiocytes and intact isolated and grouped acid-fast bacilli. Eosinophils, vasculitis, vasculopathy or signs of chronic venous insufficiency were not observed. Skin lesions improved rapidly after multidrug therapy, without any concomitant specific treatment for ulcers.
\end{abstract}

Conclusions: This series of cases highlights the importance of recognizing ulcers as a specific cutaneous manifestation of leprosy, allowing diagnosis and treatment of the disease, and therefore avoiding development of disabilities and persistence of the transmission chain of M. leprae.

Keywords: Leprosy, Mycobacterium leprae, Skin ulcer

\section{Background}

Leprosy is a chronic granulomatous infection caused by Mycobacterium leprae that is endemic in some poor resource countries. Brazil is the second country with the highest incidence of leprosy [1]. It is a polymorphic disease with a wide range of neurocutaneous manifestations, which usually appear after a long period of incubation (3-7 years). These manifestations are at least partially determined by the host's immune response, characterizing leprosy as a spectral disease. Cutaneous lesions of leprosy usually present as hypoesthetic hypochromic macules, papules, plaques, and diffuse infiltration of the skin with alopecia and xerosis [2]. Less frequent manifestations include blisters, hyperpigmented patches, verrucous lesions, macrocheilia,

\footnotetext{
* Correspondence: denisrmiyashiro@gmail.com

${ }^{1}$ Department of Dermatology, Hospital das Clínicas University of São Paulo Medical School, 255, Dr. Enéas de Carvalho Aguiar Ave, 3rd floor, São Paulo, Brazil

Full list of author information is available at the end of the article
}

and pure neural leprosy [2-6]. Extra-cutaneous involvement in multibacillary leprosy includes eyes, nasal mucosa, joints, lymph nodes, testicles, liver, and spleen [2]. Diagnosis is based on clinical findings followed by laboratory confirmation, usually the bacteriological examination of slit-skin smears performed by an experienced technician. Current serological assays identify infected individuals but are not able to diagnose all patients with leprosy. In addition, in poor-resource settings, which comprise the endemic areas, diagnosis is in most instances solely based on clinical grounds [2].

Therefore, clinical suspicion after careful examination of skin and neural alterations is of utmost importance for the diagnosis of leprosy. Unfortunately, delayed diagnosis and treatment are still an issue in endemic poorresource settings and in non-endemic countries due to global migration [7]. Ulcer is not a common feature in leprosy patients, except during reactional states, Lucio's phenomenon (LP), or secondary to neuropathies [2]. We

(c) The Author(s). 2019 Open Access This article is distributed under the terms of the Creative Commons Attribution 4.0 International License (http://creativecommons.org/licenses/by/4.0/), which permits unrestricted use, distribution, and reproduction in any medium, provided you give appropriate credit to the original author(s) and the source, provide a link to the Creative Commons license, and indicate if changes were made. The Creative Commons Public Domain Dedication waiver (http://creativecommons.org/publicdomain/zero/1.0/) applies to the data made available in this article, unless otherwise stated. 
report eight consecutive leprosy patients, diagnosed between 2010 and 2018 at a single center in São Paulo, Brazil, who had specific cutaneous ulcers that were part of their main leprosy manifestation but were not associated with reactional states, LP or neuropathies,. All patients had delayed diagnosis and seven patients had grade 2 of disability by the time of the diagnosis.

\section{Cases presentation}

From 2010 to 2018, eight of 411 patients (1.9\%) were diagnosed with multibacillary leprosy with ulcers as part of the main leprosy manifestation in our institution. All patients were male. Mean age at diagnosis of leprosy was 47.6 years (range 15.9 to 71.9 years). In all eight patients, leprosy was not associated with reactional states, LP or neuropathy. Ulcers were mostly present on lower limbs (eight patients), followed by the upper limbs (three patients), and the abdomen (one patient) (Fig. 1). Loss of sensation was observed on the lower and upper limbs in six of eight patients; on the back in one patient; and one patient had diffuse loss of sensation. Seven patients had grade 2 disability, and one had grade 1 at diagnosis. Nerve involvement (thickness) comprised: ulnar nerve (six patients), fibular nerve (five patients) and posterior tibial nerve (one patient). All patients had other leprosy associated lesions at diagnosis, as follows: madarosis (five patients), infiltration of ear lobe (four patients), perforation of nasal septae (three patients), oral vegetating and ulcerated lesion on hard palate (two patients), multiple skin-colored infiltrated papules and nodules compatible with histoid leprosy (two patients) [8], foveolar plaques (one patient), and diffuse infiltration with leonine facies (one patient). None of the patients complained of systemic symptoms. Clinical data are summarized in Table 1.

Mean time from onset of ulcers to diagnosis of leprosy was 17.4 months ( 2 months to 4 years). Biopsy of the ulcers was performed on seven patients (in patient \#2 an infiltrated papule was biopsied): all seven biopsies showed mild to moderate lympho-histiocytic infiltrate with vacuolized histiocytes. Two patients had neutrophils, and two had plasma cells on skin infiltrate. Eosinophils, vasculitis, vasculopathy or signs of chronic venous insufficiency were not observed. Fite-Faraco staining showed intact isolated and grouped acid-fast bacilli in all skin samples (Fig. 2). Histopathology of patient \#2 showed infiltrate with predominance of lymphocytes, plasma cells, histiocytes, and necrotic areas, and isolated or grouped intact acid-fast bacilli on Fite-Faraco.

Skin ulcers improved rapidly after multidrug therapy for multibacillary leprosy (MDT-MB) according to WHO recommendations. Some patients started to show partial healing after only 1 week of treatment. Complete healing of the lesions occurred after a mean of 6.9

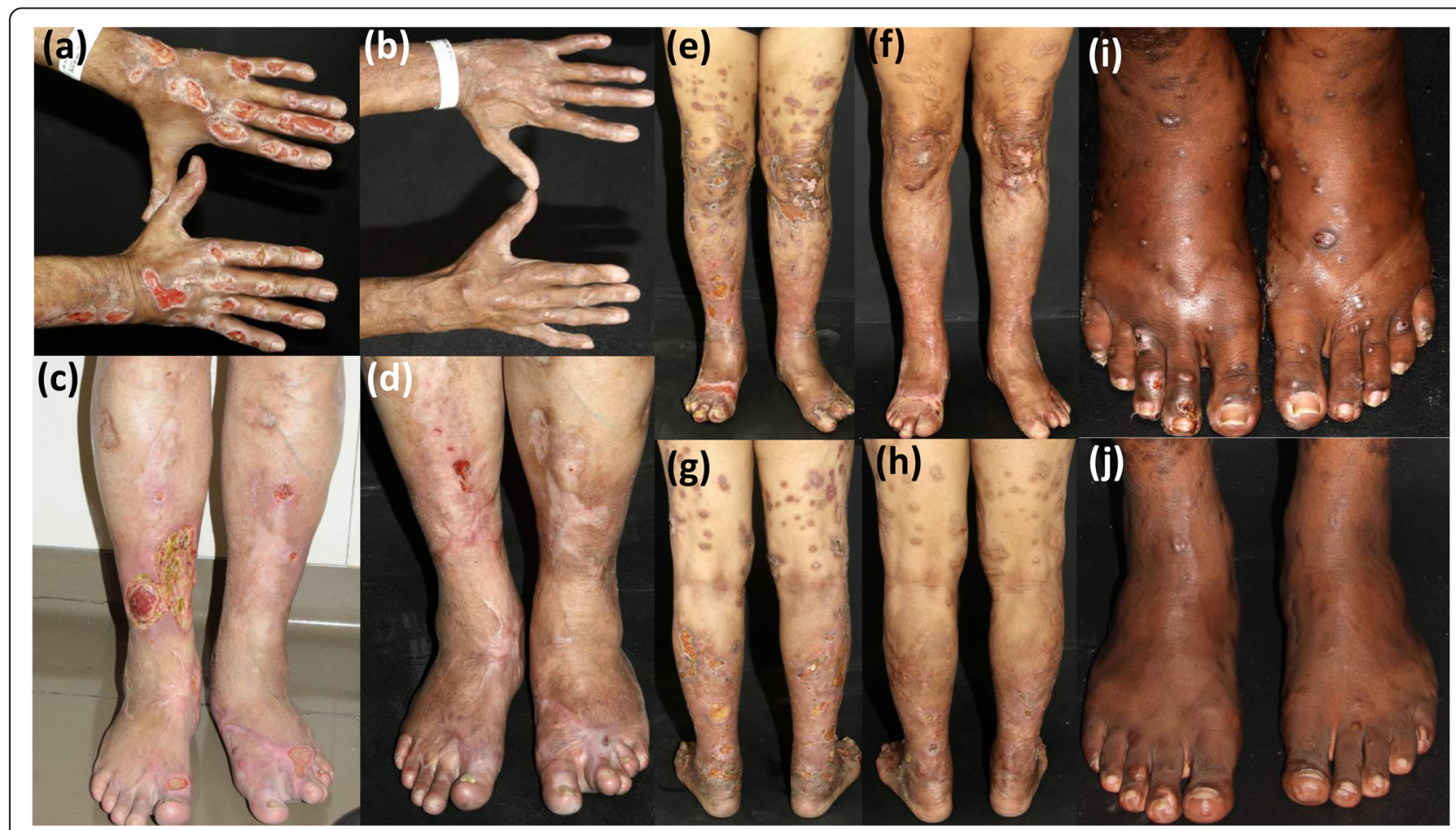

Fig. 1 Multiple ulcers on the hands and forearms before (a) and after 8 months of MDT-MB (b). Multiple ulcers on the legs and feet before (c) and after 3 months of MDT-MB (d). Multiple ulcers on the lower limbs before (e and $\mathbf{g}$ ) and after 12 months of MDT-MB (f and $\mathbf{h}$ ). Multiple infiltrated papules, nodules, and ulcerated lesions on the feet in a patients with histoid leprosy before (i) and after 7 months of MDT-MB (j) 
Table 1 Clinical findings of the patients with specific skin ulcers caused by leprosy

\begin{tabular}{|c|c|c|c|c|c|c|c|c|c|}
\hline $\begin{array}{l}\text { Case } \\
\text { number }\end{array}$ & Gender & Provenance & $\begin{array}{l}\text { Age at } \\
\text { diagnosis }\end{array}$ & $\begin{array}{l}\text { Time from the } \\
\text { appearance of } \\
\text { skin ulcers to } \\
\text { the diagnosis of } \\
\text { leprosy }\end{array}$ & $\begin{array}{l}\text { Ridley- } \\
\text { Jopling } \\
\text { classification } \\
{[9]}\end{array}$ & $\begin{array}{l}\text { Topography } \\
\text { of skin } \\
\text { ulcers }\end{array}$ & Type of other skin lesions & $\begin{array}{l}\text { Grade of } \\
\text { disability } \\
\text { at } \\
\text { diagnosis }\end{array}$ & $\begin{array}{l}\text { Time to } \\
\text { resolution } \\
\text { of ulcers } \\
\text { after start of } \\
\text { MDT-MB }\end{array}$ \\
\hline 1 & Male & $\begin{array}{l}\text { Porto União } \\
\text { - Santa } \\
\text { Catarina }\end{array}$ & 37.2 & 5 months & $\mathrm{BL}$ & $\begin{array}{l}\text { Lower and } \\
\text { upper limbs, } \\
\text { abdomen }\end{array}$ & $\begin{array}{l}\text { Perforation of nasal septae; } \\
\text { infiltration of ear lobe }\end{array}$ & Grade 2 & 12 months \\
\hline 2 & Male & $\begin{array}{l}\text { Jacobina - } \\
\text { Bahia }\end{array}$ & 15.9 & 2 years & $\mathrm{LL}$ & $\begin{array}{l}\text { Hands and } \\
\text { feet }\end{array}$ & Histoid leprosy & Grade 1 & 7 months \\
\hline 3 & Male & Nigeria & 34.5 & 3 years & $\mathrm{LL}$ & Lower limbs & Foveolar plaques & Grade 2 & 6 months \\
\hline 4 & Male & $\begin{array}{l}\text { Adamantina } \\
\text { - São Paulo }\end{array}$ & 71.9 & 4 years & $\mathrm{LL}$ & Lower limbs & Madarosis & Grade 2 & 7 months \\
\hline 5 & Male & $\begin{array}{l}\text { Cotia - São } \\
\text { Paulo }\end{array}$ & 53.6 & 1 year & $\mathrm{LL}$ & Lower limbs & $\begin{array}{l}\text { Perforation of nasal septae; } \\
\text { infiltration of ear lobe; } \\
\text { madarosis }\end{array}$ & Grade 2 & 3 months \\
\hline 6 & Male & $\begin{array}{l}\text { Adolfo - São } \\
\text { Paulo }\end{array}$ & 56.6 & 2 months & $\mathrm{BL}$ & $\begin{array}{l}\text { Lower and } \\
\text { upper limbs }\end{array}$ & $\begin{array}{l}\text { Perforation of nasal septae; } \\
\text { ulcerated vegetating lesion on } \\
\text { hard palate; madarosis }\end{array}$ & Grade 2 & 8 months \\
\hline 7 & Male & $\begin{array}{l}\text { Sousa - } \\
\text { Paraíba }\end{array}$ & 42.8 & 9 months & $B L$ & Lower limbs & $\begin{array}{l}\text { Diffuse infiltration with leonine } \\
\text { facies; histoid leprosy; ulcerated } \\
\text { vegetating lesion on hard } \\
\text { palate; infiltration of ear lobe; } \\
\text { madarosis }\end{array}$ & Grade 2 & 3 months \\
\hline 8 & Male & $\begin{array}{l}\text { Itabirito - } \\
\text { Minas Gerais }\end{array}$ & 68.3 & 3 months & $\mathrm{LL}$ & Lower limbs & $\begin{array}{l}\text { Infiltration of ear lobe; } \\
\text { madarosis }\end{array}$ & Grade 2 & 9 months \\
\hline
\end{tabular}

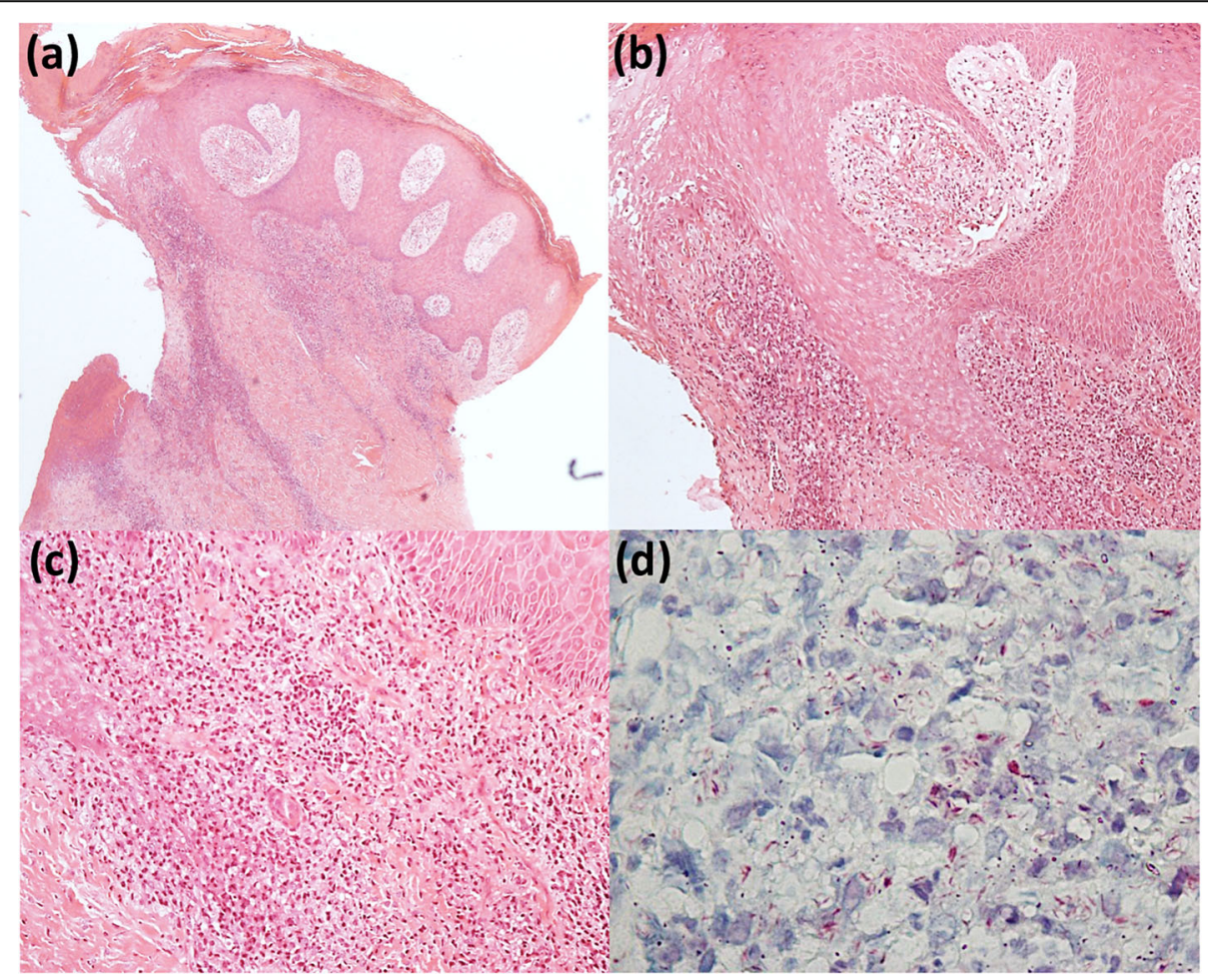

Fig. 2 a Edge and bed of chronic ulcer: epidermal hyperplasia, dermis with mixed inflammatory infiltrate and fibrosis (40x). b Detail of the edge of chronic ulcer: epidermal hyperplasia, vascular proliferation and ectasia, mixed inflammatory infiltrate (100x). c Detail of mixed inflammatory infiltrate (lymphocytes, histiocytes, neutrophils, plasma cells) (200x). d Fite-Faraco stain with intact isolated and grouped acid-fast bacilli 
months (range: 1-12 months) on MDT-MB. No other specific treatment for ulcers was prescribed.

\section{Discussion and conclusions}

Patients with leprosy rarely present ulcerated lesions; these can eventually appear during reactional sates, LP, or secondary to neuropathy, the latter particularly on the plantar surfaces [10]. In general, healing of the ulcerated neuropathic lesions is very slow, due to the vascular and neural disabilities that underlie these manifestations, requiring specific therapeutic interventions in addition to MDT-MB. LP is a rare complication of multibacillary leprosy, due to massive bacilli invasion of endothelial cells causing a thrombotic syndrome, where the initial macular lesion is purpuric. Also, LP usually starts before treatment, and histology shows thrombosis with or without necrosis of small vessels [11]. None of our patients presented clinical or histopathological evidence of LP or reactional states, or a history of ulcers related to trauma. The fast healing of ulcers with MDT-MB alone was a clue to the diagnosis of specific skin ulcer caused by leprosy, which was confirmed by positive bacilloscopy of skin specimens. In type two reaction, skin lesions usually start during leprosy treatment, neutrophils are a hallmark, and acid-fast bacilli, when present, are fragmented $[11,12]$; in the two patients with neutrophils on skin specimens, the acid-fast bacilli were intact, and the rapid response to MDT-MB with no treatment for reactional states confirmed the diagnosis of specific skin ulcers caused by leprosy.

Delayed diagnosis or misdiagnosis contributes to advanced disease and irreversible disabilities. Only three of eight patients were diagnosed with less than 6 months since onset of the lesions. Patient \#4 had lower limb ulcers for 4 years before the diagnosis of leprosy. He had been treated for venous insufficiency without improvement, had skin ulcers and diffuse infiltration of the skin, alopecia, hypochromic and erythematous macules, and grade two disability, raising the suspicion of leprosy. Patient \#2 had skin lesions since 13 years-old, but was diagnosed only 2 years later. At diagnosis, he had multiple infiltrated papules and nodules, some of them ulcerated, and loss of sensation on lower limbs; he was diagnosed as histoid leprosy (Fig. 1i-j). He promptly responded to MDT-MB and was the single patient who did not develop permanent deforming disabilities.

It is not clear why leprosy lesions progressed to ulcer formation. The pathogenesis of skin ulcers is still a subject of intense research, especially of chronic venous leg ulcers [13]. These studies showed that a range of vascular alterations results in a final common path: a chronic and poorly regulated subcutaneous inflammatory process that ultimately causes necrosis and ulceration [14]. In fact, the inflammatory process described in chronic venous ulcers share some features with the inflammatory response of lepromatous leprosy, but not with that of tuberculoid leprosy, where the inflammatory response is well organized, typically with compact granulomas, rarely resulting in necrosis. Similar to lepromatous leprosy, in venous ulcers there is a cellular infiltration with predominance of macrophages, followed by T-lymphocytes, which are important in the events preceding ulceration [15]. As in leprosy, the infiltrating macrophages were associated with production of tumor necrosis factor [16]. In addition, among the main factors generated by the venous ulcer inflammatory process that contribute to necrosis and ulceration are reactive oxygen species [13, 14]. In leprosy, studies have showed that multibacillary, but not paucibacillary patients, had enhanced oxidative stress [17]. Although these findings unveil possible mechanisms for ulceration in lepromatous leprosy lesions, it remains to be established why this occurs in only a subset of patients.

In addition to M. leprae, M. lepromatosis was also recognized as etiologic agent for leprosy in 2008 [18]. The first reports of these mycobacteria were described in two Mexican patients who died of diffuse lepromatous leprosy. This species was initially associated with diffuse lepromatous leprosy as well as lepromatous leprosy [18]. However, more recently, an analysis of 46 Brazilian patients with leprosy showed that $M$. lepromatosis was present in seven patients, all with tuberculoid leprosy [19]. Unfortunately it was not possible to determine the infecting species in our patients. Whether the infection with $M$. lepromatosis is associated with specific clinical manifestations in Brazil, including development of specific skin ulcers, is not yet known.

This series of cases highlights the importance of recognizing ulcers as a specific cutaneous manifestation of leprosy. Ulcerated lesions should be considered as a clinical manifestation of leprosy, allowing early diagnosis and treatment, and therefore avoiding development of disabilities and persistence of the transmission chain of M. leprae.

\section{Abbreviations \\ LP: Lucio's phenomenon; MDT-MB: multidrug therapy for multibacillary leprosy}

\section{Acknowledgements}

We thank Dr. Valeria Aoki for reviewing the manuscript.

\section{Authors' contributions}

DM designed the research, analyzed the data, and wrote the paper. CC analyzed the data and revised the paper. NYSV reviewed histopathology and revised the paper. JA participated in sample collection and revised the paper GB analyzed the data, revised the paper and supervised the study. MABT participated in sample collection, revised the paper and supervised the study. All authors have read and approved the submitted version of this manuscript. 
Funding

None.

\section{Availability of data and materials}

The datasets used or analyzed for this study are available from the corresponding author.

\section{Ethics approval and consent to participate}

As a retrospective study, no additional interventions were made for the study. A written consent to participate was obtained from the patients or a legal parent.

\section{Consent for publication}

Written informed consent for publication of this case report and any accompanying images was obtained from each patient or the legal guardian in the case of those under the age of 18 years old. The patients were made aware of the fact that their anonymity cannot be fully guaranteed and that there is a possibility that they could be identified based on the case report information/images

A copy of the written consent is available for review by the Editor of this journal.

\section{Competing interests}

The authors declare that they have no competing interests.

\section{Author details}

'Department of Dermatology, Hospital das Clínicas University of São Paulo Medical School, 255, Dr. Enéas de Carvalho Aguiar Ave, 3rd floor, São Paulo, Brazil. ${ }^{2}$ Laboratory of Clinical and Experimental Allergy and Immunology LIM-56, University of São Paulo Medical School, São Paulo, Brazil. ${ }^{3}$ Laboratory of Medical Mycology LIM-53, University of São Paulo Medical School, São Paulo, Brazil. ${ }^{4}$ Institute of Tropical Medicine of São Paulo, University of São Paulo Medical School, São Paulo, Brazil.

Received: 27 April 2019 Accepted: 19 November 2019

Published online: 29 November 2019

\section{References}

1. World Health Organization. Global leprosy update, 2017: reducing the disease burden due to leprosy. Wkly Epidemiol Rec. 2018;35(93):445-56.

2. Britton WJ, Lockwood DNJ. Leprosy. Lancet. 2004;363(9416):1209-19.

3. Handa S, Saraswat A, Radotra BD, Kumar B. Chronic macrocheilia: a clinicopathological study of 28 patients. Clin Exp Dermatol. 2003;28(3):245-50.

4. Ghorpade A. Multiple superficial sporotrichoid nerve abscesses with a hyperpigmented lesion in a tuberculoid leprosy patient: a rare and unusual presentation. J Eur Acad Dermatol Venereol. 2006;20(3):357-8.

5. Agarwal US, Mehta S, Kumar R, Besarwal RK, Agarwal P. Bullous lesions in leprosy: a rare phenomenon. Indian J Dermatol Venereol Leprol. 2013;79(1): $107-9$.

6. Medeiros MZ, Hans Filho G, Takita LC, Vicari CFS, Barbosa AB, Couto DV. Verrucous lepromatous leprosy: a rare form of presentation - report on two cases. An Bras Dermatol. 2014;89(3):481-4.

7. Trindade MA, Varella TC, Cisneros CG, Bottini V, Moura AK. Delayed diagnosis of multibacillary leprosy: a report of eight cases. Braz J Infect Dis. 2009;13(2):155-7.

8. Canuto MJM, Yacoub CRD, Trindade MAB, Avancini J, Pagliari C, Sotto MN. Histoid leprosy: clinical and histopathological analysis of patients in followup in university clinical hospital of endemic country. Int J Dermatol. 2018; 57(6):707-12.

9. Ridley SD, Jopling WH. Classification of leprosy according to immunity. A five-group system. Int J Lepr Other Mycobact Dis. 1966;34(3):255-73.

10. Fernandes TR, Santos TS, Lopes RR. Leg ulcer in lepromatous leprosy - case report. An Bras Dermatol. 2016:91(5):673-5.

11. Benard G, Sakai-Valente NY, Bianconcini Trindade MA. Concomitant lucio phenomenon and erythema nodosum in a leprosy patient: clues for their distinct pathogeneses. Am J Dermatopathol. 2009;31(3):288-92.

12. Kamath $\mathrm{S}$, Vaccaro $\mathrm{SA}$, Rea TH, Ochoa MT. Recognizing and managing the immunologic reactions in leprosy. J Am Acad Dermatol. 2014;71(4):795-803.

13. Raffetto JD. Pathophysiology of chronic venous disease and venous ulcers. Surg Clin North Am. 2018;98(2):337-47.
14. Chen WY, Rogers AA. Recent insights into the causes of chronic leg ulceration in venous diseases and implications on other types of chronic wounds. Wound Repair Regen. 2007;15(4):434-49.

15. Wilkinson LS, Bunker CS, Edwards JCW, Scurr JH, Smith PD. Leukocytes: their role in the etiopathogenesis of skin damage in venous disease. J Vasc Surg. 1993;17(4):669-75.

16. Claudy AL, Mirshahi M, Soria C, Soria J. Detection of undegraded fibrin and tumor necrosis factor-alpha in venous leg ulcers. J Am Acad Dermatol. 1991;25(4):623-7.

17. Reddy YN, Murthy SV, Krishna DR, Prabhakar MC. Oxidative stress and antioxidant status in leprosy patients. Indian J Lepr. 2003:75(4):307-16.

18. Han XY, Seo Y-H, Sizer KC, Schoberle T, May GS, Spencer JS, et al. A new Mycobacterium species causing diffuse lepromatous leprosy. Am J Clin Pathol. 2008;130:856-64.

19. Han XY, Aung FM, Choon SE, Werner B. Analysis of the leprosy agents Mycobacterium leprae and Mycobacterium lepromatosis in four countries. Am Clin Pathol. 2014;142:524-32

\section{Publisher's Note}

Springer Nature remains neutral with regard to jurisdictional claims in published maps and institutional affiliations.

\section{Ready to submit your research? Choose BMC and benefit from:}

- fast, convenient online submission

- thorough peer review by experienced researchers in your field

- rapid publication on acceptance

- support for research data, including large and complex data types

- gold Open Access which fosters wider collaboration and increased citations

- maximum visibility for your research: over $100 \mathrm{M}$ website views per year

At BMC, research is always in progress.

Learn more biomedcentral.com/submissions 